\title{
Phytoscreening and phytoextraction of heavy metals at Danish polluted sites using willow and poplar trees
}

\author{
Mette Algreen • Stefan Trapp • Arno Rein
}

Received: 20 April 2013 / Accepted: 21 August 2013 / Published online: 7 September 2013

(C) The Author(s) 2013. This article is published with open access at Springerlink.com

\begin{abstract}
The main purpose of this study was to determine typical concentrations of heavy metals (HM) in wood from willows and poplars, in order to test the feasibility of phytoscreening and phytoextraction of HM. Samples were taken from one strongly, one moderately, and one slightly polluted site and from three reference sites. Wood from both tree species had similar background concentrations at $0.5 \mathrm{mg} \mathrm{kg}^{-1}$ for cadmium (Cd), $1.6 \mathrm{mg} \mathrm{kg}^{-1}$ for copper (Cu), $0.3 \mathrm{mg} \mathrm{kg}^{-1}$ for nickel (Ni), and $25 \mathrm{mg} \mathrm{kg}^{-1}$ for zinc ( $\mathrm{Zn}$ ). Concentrations of chromium (Cr) and lead $(\mathrm{Pb})$ were below or close to detection limit. Concentrations in wood from the highly polluted site were significantly elevated, compared to references, in particular for willow. The conclusion from these results is that tree coring could be used successfully to identify strongly heavy metal-polluted soil for $\mathrm{Cd}, \mathrm{Cu}, \mathrm{Ni}, \mathrm{Zn}$, and that willow trees were superior to poplars, except when screening for Ni. Phytoextraction of HMs was quantified from measured concentration in wood at the most polluted site. Extraction efficiencies were best for willows and $\mathrm{Cd}$, but below $0.5 \%$ over 10 years, and below $1 \%$ in 10 years for all other HMs.
\end{abstract}

Responsible editor: Elena Maestri

Electronic supplementary material The online version of this article (doi:10.1007/s11356-013-2085-z) contains supplementary material, which is available to authorized users.

M. Algreen $(\bowtie) \cdot S$. Trapp

Department of Environmental Engineering, Technical University of

Denmark, Miljøvej building 113, DK-2800 Kongens Lyngby,

Denmark

e-mail: mann@env.dtu.dk

\section{A. Rein}

Chair of Hydrogeology, Faculty of Civil, Geo and Environmental

Engineering, Technische Universität München, Arcisstr. 21,

80333 Munich, Germany
Keywords Extraction efficiencies · Phytoremediation · Phytotechnologies · Plant uptake · Soil contamination · Toxic elements $\cdot$ Tree core sampling $\cdot$ Wood

\section{Background, aim, and scope}

The examination of subsurface pollution by analyzing tree cores was started in the 1990s in the USA (Schumacher et al. 2004; Vroblesky et al. 1999). Today, phytoscreening of soil and groundwater has become a scientifically validated and recognized method (Sorek et al. 2008; Gopalakrishnan et al. 2007) and has frequently been used to investigate plumes of chlorinated solvents, such as tetrachloroethene, trichloroethene, and cis-1,2-dichloroethene (Sorek et al. 2008; Larsen et al. 2008). The principle underlying the method is that contaminants are taken up by roots and translocated upwards to the stem. By use of a borer, tree cores can be taken from the trunks of trees for chemical analysis. The presence of subsurface pollutants in the wood was found to indicate the presence of these pollutants in soil and/or groundwater (Burken et al. 2011).

Using tree core sampling as a phytoscreening technique for chlorinated solvents is now an established technique (Holm et al. 2011; Vroblesky 2008; Trapp et al. 2007) with beginning commercial use. Recent developments include applying solidphase microextraction methods for in planta quantification of chlorinated compounds (Sheehan et al. 2012). However, what works so well for volatile organic compounds seems to provide more difficulties for heavy metals (HM). Algreen et al. (2012) tested tree coring of toxic elements and HMs for an abandoned waste site in Norway by comparing concentrations in wood samples from the test site with concentrations in samples from reference sites. In most cases, the concentrations of the investigated elements were higher in wood from the test site. But the authors also found a high variation in heavy metal content of 
the wood, and a dependency on tree species. This may be due to the fact that several heavy metals are essential for plant growth (McLaughlin et al. 2011). The mere occurrence of HM in wood does, therefore, not indicate elevated levels or pollution of subsurface. Willows (Salix sp.) and poplars (Populus sp.) usually had the highest contents of HM in wood, compared to other tree species, and were preferably sampled. However, the observed differences between contaminated test site and (nominally) unpolluted reference site were not always statistically significant. A main conclusion from that study was that phytoscreening with tree cores is more difficult to use for HM than for chlorinated solvents. Overall, tree coring seemed a promising way to find subsurface contamination, but the results of the study did not allow a final judgment of the feasibility of this method for HM (Algreen et al. 2012).

Numerous studies deal with the uptake of HM into vegetation (McLaughlin et al. 2011). For example, the BAPPET database (2008) reports measured concentrations of metals in plant tissue and soil, with many thousand entries. Most crops and vegetables are considered, but there are no data on wood. Generally, only few scientific studies focused on HM concentrations in wood (Algreen et al. 2012). This is quite surprising, giving the high interest in phytoextraction of metals. Rock (2003) gives an overview of 33 field trials for phytoremediation, and trees such as willow (Salix sp.) and hybrid poplar (Populus sp.) are among the most frequently used species. However, in most of these field studies, the effect of phytoextraction on metal concentrations in soil was negligible or insignificant. Elevated heavy metal concentrations in vegetation have also been used for prospecting ore deposits (Hohl 1981).

We applied the tree coring method and took wood samples from willows (Salix sp.) and poplars (Populus sp.) at three polluted test sites and three non-polluted reference sites in Denmark. The concentrations of cadmium $(\mathrm{Cd})$, chromium $(\mathrm{Cr})$, copper $(\mathrm{Cu})$, nickel $(\mathrm{Ni})$, lead $(\mathrm{Pb})$, and zinc $(\mathrm{Zn})$ in wood and soil were analyzed and evaluated. Goals of this study were to determine typical concentrations of HM in wood from willows and poplars and to investigate tree core sampling as a low invasive screening method. The latter included testing for differences of HM concentrations in wood from trees growing under background conditions and on polluted sites, testing for differences in HM uptake between the two tree species, and studying the relation between HM in soil and wood. Another goal was to evaluate the feasibility of $\mathrm{HM}$ extraction from contaminated sites by performing a mass balance, based on a 10-year field trial.

\section{Materials and methods}

Test sites

Three test sites located in Denmark were selected for tree core and soil sampling (Fig. S1 in the Supporting Information).
Test site 1, Valby Most samples were taken from the former sludge disposal site in Valby. The site is distant from traffic and close to the Baltic Sea. The site has a known high pollution with organic and inorganic pollutants and was from 1999 to 2005 used as phytoremediation test site by the Danish Environmental Protection Agency (Oberender et al. 2009). Willows (Salix viminalis varieties) and poplars (mostly Populus trichocarpa) were planted in 1999 at the site in two separate areas (Fig. S1a). Approximately $15 \%$ of the trees died the first year, and additional trees were planted in 2000. Remaining trees have shown good growth, but some trees had curled and spotted leaves indicating stress and/or diseases (Oberender et al. 2009). The concentrations of $\mathrm{Cd}, \mathrm{Cr}, \mathrm{Cu}, \mathrm{Pb}, \mathrm{Ni}$, and $\mathrm{Zn}$ (among others) in the soil are high (up to 30, 1,300, 700, 200, 4,400 , and $6,200 \mathrm{mg} \mathrm{kg}^{-1}$ total soil dry weight, respectively), classifying the soil as strongly polluted. Samples from trees growing in the arboretum in Hørsholm, North Sealand, Denmark, were taken as reference.

Test site 2, Frederiksvcerk A second sampling site is a steel work in Frederiksværk (Fig. S1b). Hazardous waste was deposited at the site from 1942 to the late 1980s. The waste consisted of steel scrap and dross from the production, but also chemicals used in the production. The major pollutants at the site were $\mathrm{Cd}$, $\mathrm{Cr}, \mathrm{Cu}, \mathrm{Pb}$, and $\mathrm{Zn}$. The zones with highest contamination were remediated and are without trees. A site with lower HM content, labeled as "potentially polluted zone" was used for this study. Further information about the site is not available. The reference site was a presumably unpolluted area nearby.

Test site 3, Hillerød Between 1936 and 1976, this site was used as wood proofing facility (Fig. S1c). This resulted in a heterogeneous soil contamination with arsenic, chromium, and copper. The site has not been remediated (further details are reported by Skov og Naturstyrelsen 1989a, b). Reference samples were taken nearby, from an area assumed to be unpolluted.

\section{Sampling}

Tree cores Sampling was done according to the Guide to Phytoscreening (Holm et al. 2011). Tree core samples were taken at a height of $1 \mathrm{~m}$ using a $6 \mathrm{~mm}$ increment borer (Suunto, Finland). Three tree cores with a length of $6 \mathrm{~cm}$ where taken around the tree. The outer centimeter, containing the bark and the phloem, was discarded to avoid atmospheric influence. The tree cores from each tree were mixed together in plastic bags for storage until sample preparation. Tree core sampling from test site 1 was performed first in June and September 2011, and 18 samples from willows (S. viminalis) and 18 from poplars $(P$. trichocarpa) were taken. From the reference site, Arboretum in Hørsholm, four willows (Salix 
sp.), and four poplars (Populus sp.) were sampled late September 2011. At test site 2, 18 poplars (Populus nigra) arranged in a line, as well as two poplars from the nearby reference site were sampled in spring 2010. At test site 3, nine willows (Salix sp.) placed at three locations and two willows from the reference site were sampled in summer 2010.

Soil samples The content of HM in soil was analyzed in soil samples from each test site. Each soil sample consisted of three soil cores down to $0.7-\mathrm{m}$ depth around the crown of the tree. The upper $20 \mathrm{~cm}$ (top soil) were removed and the remaining soil was mixed together to one sample. The samples were stored in plastic bags until preparation for analysis. The number of samples varied between sites, depending on the site conditions (presence and location of trees, accessibility for soil sampling). From test site 1, three samples from the area of willows and five samples from the area of poplars were taken in the beginning of June 2011. From test site 2, eight soil samples (from every second tree) and from test site 3 three soil samples (one from each area) were sampled additionally with the tree core samples. One soil sample from the reference sites were also taken. Sampling at test site 1 in 2001 is described by Oberender et al. (2009).

Sample preparation and analytical method

Tree core samples Tree core samples were divided into smaller pieces and dried at $75^{\circ} \mathrm{C}$ for approximately $24 \mathrm{~h}$ to constant weight. Between 0.5 to $0.8 \mathrm{~g}$ of the dried sample were weighed into a 50-ml volumetric flask (in duplicates). Ten milliliter $65 \% \mathrm{HNO}_{3}$ was added, and the flask was placed on a sand bath at $70-80{ }^{\circ} \mathrm{C}$ or until the wood was dissolved (approximately $2 \mathrm{~h}$ ). Flasks were then removed and cooled at room temperature for $10 \mathrm{~min}$ before $2.5 \mathrm{ml} 30 \% \mathrm{H}_{2} \mathrm{O}_{2}$ was added. The flasks were placed back on the sand bath until the gas reaction was completed. The procedure was repeated with additional $2.5 \mathrm{ml} 30 \% \mathrm{H}_{2} \mathrm{O}_{2}$. Milli-Q water was added to a volume of $50 \mathrm{ml}$, and the flask was shaken. Approximately $3 \mathrm{ml}$ of the sample was transferred to a centrifuge glass, the glass was shaken and emptied. The rest of the sample was transferred to the same centrifuge glass and centrifuged for $10 \mathrm{~min}$ with $2,500 \mathrm{rpm}$. The supernatant was transferred to plastic (PE) bottles for storage at room temperature. Seven milliliter of sample was transferred to the test tube for analysis.

Soil samples Soil samples were dried at approximately $23{ }^{\circ} \mathrm{C}$ for 3 days to constant weight. For measurements of the total concentration, further sample preparation was done analogue to the sample preparation of the tree core samples. For measurement of the easily extractable concentration of HM, approximately $8 \mathrm{~g}$ soil was weighed into blue cap bottles (in duplicates) and $90 \mathrm{ml} 1 \mathrm{mM} \mathrm{CaCl} 2$ was added. The bottles were placed on a shaking bench for $24 \mathrm{~h}$. After shaking, approximately $3 \mathrm{ml}$ of sample were transferred to a centrifuge glass, shaken, and emptied. The rest of the sample was transferred to the same centrifuge glass and centrifuged for $10 \mathrm{~min}$ with $2,500 \mathrm{rpm}$. The supernatant was transferred to plastic (PE) bottles for storage at room temperature. Seven milliliter of sample was transferred to test tubes for analysis. Preparation and analysis of soil samples taken in 2001 at test site 1 are described in Oberender et al. (2009).

All equipment used for sample preparation was acid washed before use. All soil samples were prepared and analyzed after working with the tree core samples to avoid contamination of the tree core samples from the soil samples.

Analytical method All analyses were performed on inductively coupled plasma optical emission spectrometry (Varian, VistaMPX) and with an internal standard (Yttrium $1 \mathrm{mg} / \mathrm{L} / \mathrm{HNO}_{3}$ $1 \% \mathrm{w} / \mathrm{w}$ ). The calibration curves were done from nine standards in the concentration interval of $0.3-1,012 \mu \mathrm{g}$ metal/L. Samples measured above $1,012 \mu \mathrm{g}$ metal/L were diluted and reanalyzed. Six metals were analyzed as follows: $\mathrm{Cd}(228.802 \mathrm{~nm} \lambda), \mathrm{Cr}$ $(205.560 \mathrm{~nm} \lambda), \mathrm{Cu}(327.395 \mathrm{~nm} \lambda), \mathrm{Ni}(231.604 \mathrm{~nm} \lambda), \mathrm{Pb}$ $(220.353 \mathrm{~nm} \lambda)$, and $\mathrm{Zn}(206.200 \mathrm{~nm} \lambda)$. All concentrations in soil and wood are given for the dry weight.

Quality control The method of sample preparation was validated by comparison to the referenced soil standard QC loam soil (Sigma-Aldrich, DK). The analytical method was validated by spike samples, controls, method blank samples, and total blank samples. Measurements below detection limit (DL) were adjusted to $1 / 2$ of DL (data for DL are shown in Table S1, Supporting Information).

\section{Calculations}

Statistical tests The normal distribution of the Valby data was tested by a Kolmogorov-Smirnov test at $\alpha=5 \%$, and normal distribution could not be rejected in any case. Therefore, parametrical statistical tests were used. A two-tailed $t$ test with error probability of $0.05(\alpha=5 \%)$ was applied to test for significance of differences between mean concentration in wood and soil from test and reference sites, and from willows and poplars. The relation between concentrations of $\mathrm{HM}$ in wood and soil (total and easily extractable concentration) was evaluated by Pearson linear correlation and regression analysis.

Bioconcentration factor in trees The bioconcentration factor (BCF) was calculated from the concentration of metals measured in wood $C_{\text {Wood }}$ (in milligrams per kilogram) divided by 
the total metal concentration measured in the soil $C_{\text {Soil }}$ (in milligrams per kilogram) as follows:

$B C F=C_{\text {Wood }} / C_{\text {Soil,total }}$

The BCF values were derived as the average of each sample pair (wood vs. soil) at each site and for each tree species. At test sites 2 and 3, more than one tree core sample was related to one soil sample, and average concentrations in wood were used for the calculation.

Alternatively, the $\mathrm{BCF}$ was derived from the slope of the regression between $C_{\text {Wood }}$ and $C_{\text {Soil }}$ (Trapp and Legind 2011). The advantage is that both low and high concentrations contribute. A second advantage is that the Y-intercept of the regression can be interpreted as background concentration of HM in wood which is independent of the concentration in soil. The strength of the relation between $C_{\text {Wood }}$ and $C_{\text {Soil }}$ can be judged from the coefficient of determination $\mathrm{R}^{2}$, which describes the variance in $\mathrm{Y}$ (concentration in wood) that is explained by the regression to concentration in soil. The slope is significant when $R^{2}>R_{\text {crit }}^{2}$ (Sachs 1992).

Mass balance calculations Metal concentrations in soil from test site 1 were obtained in 2001 and 2011. Additionally, the removal of HM from soil due to phytoextraction by trees can be calculated as follows:

$\Delta m=-\Delta M_{\text {Wood }} \times C_{\text {Wood }}$

Where $\Delta m$ (in milligrams) is the mass of HM extracted from soil, $C_{\text {wood }}$ is the measured concentration of $\mathrm{HM}$ in wood and $\Delta M_{\text {wood }}$ is the mass of wood grown in the 10 years since planting (approximately $10 \mathrm{~kg} \mathrm{~m}^{-2}$ for willows and $15 \mathrm{~kg} \mathrm{~m}^{-2}$ for poplar (BSELF 2012)). These typical values do not consider possible growth reductions due to toxic effects by soil contamination. The resulting change in concentration depends on the soil volume assumed for extraction. With a depth of $0.7 \mathrm{~m}$ (maximum depth of soil samples) and a typical soil dry density of $1.3 \mathrm{~kg} \mathrm{~L}^{-1}$, the soil mass $M_{\text {soil }}$ is $910 \mathrm{~kg}$. The calculated change of concentration in soil over the 10 years $\Delta C$ (in milligrams per kilogram) is as follows:

$\Delta C_{\text {Soil }}=\Delta m / M_{\text {Soil }}$

Calculations of the time span $t$ (in year) required to reach the legal standards by phytoextraction were done assuming constant wood growth and BCF. Based upon the equations above, the differential equation for the change of concentration in soil is obtained as follows:

$\frac{d C_{\text {Soil }}}{d t}=-B C F \times \frac{d M_{\text {Wood }}}{d t \times M_{\text {Soil }}} \times C_{\text {Soil }}=-k \times C_{\text {Soil }}$
Where $\mathrm{d} M_{\text {Wood }} / \mathrm{d} t$ (in kilograms per year) is the change of wood mass with time. With a constant extraction rate coefficient $k$ (per year), it follows from the analytical solution that the time $t$ to reach $C_{\text {Soil }}(\mathrm{t})$ (here: legal standard) is as follows:

$t=\frac{\left(\ln \left(C_{\text {Soil }}(0) / C_{\text {Soil }}(t)\right)\right.}{k}$

\section{Results}

Concentrations in soil The measured total and easily extractable concentrations of HM in soil from the test and reference sites are shown in Table 1. Average and range (minimum to maximum, using all duplicates) are given there, and Table S2 (Supporting Information) provides also standard deviation, median, minimum, and maximum. All concentrations of HM in total soil were above DL, but results for the easily extractable concentration were often below. For all sites, median and average are similar, indicating symmetrical distribution of data (Table S2). Generally, concentrations were highest for $\mathrm{Zn}$ and lowest for $\mathrm{Cd}$. There is large difference between the sites, with test site 1 having by far the highest concentrations of all metals, followed by test site 2 . Test site 3 and the reference sites have similar, and low, level of pollution in soil. Thus, tree core sampling results from test site 1 are of most relevance for the test of tree coring as a screening method.

Concentrations in tree cores Concentrations measured in the tree core samples are summarized in Table 1 (for more details see Table S3, Supporting Information). The average and range of metal concentrations in willows and poplars can also be seen in Fig. 1. The concentrations of $\mathrm{Cd}, \mathrm{Cu}, \mathrm{Ni}$, and $\mathrm{Zn}$ in wood were in all, except a few cases, above DL. For $\mathrm{Cr}$ and $\mathrm{Pb}$, almost all concentrations in wood were below DL and are not shown and not evaluated further. Willows showed generally higher concentrations of $\mathrm{Cd}, \mathrm{Cu}$, and $\mathrm{Zn}$ than poplars. Only for Ni, poplars had the higher concentration in wood.

Significant differences in concentrations from test and reference sites The statistical significance of differences between results from test and reference site was tested both for concentrations in soil and in wood (Table S4, Supporting Information). The total concentrations in soil of test site 1 and 2 were significantly higher than in their reference sites. Contrary, test site 3 had significantly lower levels of HM than reference site 3 , except for $\mathrm{Cu}$. For the easily extractable concentrations in soil, the difference was significant for all HM on test and reference site 1 . For test and reference site 2, the difference in easy extractable $\mathrm{HM}$ was also significant except for $\mathrm{Cd}$. There was no significant difference for test and reference site 3. For wood, the differences in concentration from test and reference site 1 were all significant, except $\mathrm{Cu}$ in poplar wood. At test site 2, no 
Table 1 Total and easily extractable concentrations of HM in soil and HM concentration in wood (average values, ranges given in brackets)

\begin{tabular}{|c|c|c|c|c|c|c|}
\hline & $\mathrm{C}_{\text {Soil,total }}\left(\mathrm{mg} \mathrm{kg}^{-1}\right)$ & $\mathrm{C}_{\text {Soil,extractable }}\left(\mathrm{mg} \mathrm{kg}^{-1}\right)$ & $\mathrm{C}_{\text {Wood }}\left(\mathrm{mg} \mathrm{kg}^{-1}\right)$ & $\mathrm{C}_{\text {Soil,total }}\left(\mathrm{mg} \mathrm{kg}^{-1}\right)$ & $\mathrm{C}_{\text {Soil,extractable }}\left(\mathrm{mg} \mathrm{kg}^{-1}\right)$ & $\mathrm{C}_{\text {Wood }}\left(\mathrm{mg} \mathrm{kg}^{-1}\right)$ \\
\hline & \multicolumn{3}{|l|}{ Test site 1 , willow area } & \multicolumn{3}{|c|}{ Reference site 1 , willow area } \\
\hline & \multicolumn{2}{|l|}{3 soil samples, $n=6$} & 18 trees, $n=36$ & \multicolumn{2}{|l|}{3 soil samples, $n=6$} & 4 trees, $n=8$ \\
\hline $\mathrm{Cd}$ & $23.9(16.8-33.9)$ & $0.014(0.005-0.027)$ & $3.08(0.84-4.75)$ & $0.23(0.21-0.26)$ & $0.0036(0.0022-0.0055)$ & $0.65(0.24-1.6)$ \\
\hline $\mathrm{Cu}$ & $588(443-708)$ & $1.98(1.38-2.67)$ & $10.7(1.96-33.4)$ & $4.36(3.93-5.16)$ & $0.025(0.013-0.029)$ & $1.68(1.3-2.59)$ \\
\hline $\mathrm{Ni}$ & $132(89.3-166)$ & $0.97(0.64-1.23)$ & $0.48(0.28-1.24)$ & $4.51(4.27-4.96)$ & $0.026(0.012-0.044)$ & $0.095(0.081-0.12)$ \\
\hline \multirow[t]{3}{*}{$\mathrm{Zn}$} & $3,270(2,236-4,403)$ & $2.20(1.28-4.33)$ & $106(55.1-188)$ & $26.7(22.6-31.5)$ & $0.10(0.046-0.19)$ & $21.6(13-31.4)$ \\
\hline & \multicolumn{3}{|l|}{ Test site 1 , poplar area } & \multicolumn{3}{|c|}{ Reference site 1 , poplar area } \\
\hline & \multicolumn{2}{|l|}{5 soil samples, $n=10$} & 18 trees, $n=36$ & \multicolumn{2}{|l|}{3 soil samples, $n=6$} & 4 trees, $n=8$ \\
\hline $\mathrm{Cd}$ & $10.9(8.64-14.5)$ & $0.012(0.0071-0.016)$ & $0.62(0.36-1.17)$ & $0.42(0.11-1.06)$ & $0.0022(0.0022-0.0023)$ & $0.52(0.16-1.17)$ \\
\hline $\mathrm{Cu}$ & $651(575-736)$ & $2.57(2.08-3.01)$ & $1.21(0.69-2.82)$ & $11.7(1.53-29.4)$ & $0.033(0.013-0.058)$ & $1.11(0.57-2.95)$ \\
\hline $\mathrm{Ni}$ & $153(104-212)$ & $1.89(1.2-2.32)$ & $0.74(0.41-1.97)$ & $7.37(3.48-16.6)$ & $0.043(0.035-0.056)$ & $0.49(0.081-0.85)$ \\
\hline \multirow[t]{3}{*}{$\mathrm{Zn}$} & $2,964(2,481-3,500)$ & $3.82(2.57-4.94)$ & $32.9(19.8-76.1)$ & $20.9(11.1-44.6)$ & $0.072(0.047-0.12)$ & $25.3(6.54-76.1)$ \\
\hline & \multicolumn{3}{|l|}{ Test site 2 (poplars) } & \multicolumn{3}{|c|}{ Reference site 2 (poplars) } \\
\hline & 8 soil samples, $n=16$ & & 18 trees, $n=36$ & 1 soil sample, $n=2$ & & 2 trees, $n=4$ \\
\hline $\mathrm{Cd}$ & $0.99(0.29-3.45)$ & $0.0057(0.0015-0.011)$ & $0.42(0.21-0.67)$ & $0.43(0.31-0.54)$ & $0.0025(0.0015-0.0036)$ & $0.52(0.28-0.74)$ \\
\hline $\mathrm{Cu}$ & $67.4(9-169)$ & $0.43(0.11-0.91)$ & $1.64(0.99-3.03)$ & $8.34(7.82-8.85)$ & $0.11(0.11-0.11)$ & $1.20(1.09-1.35)$ \\
\hline $\mathrm{Ni}$ & $15.8(6.25-36.3)$ & $0.077(0.011-0.2)$ & $0.34(0.12-0.75)$ & $6.11(4.72-7.51)$ & $0.014(0.011-0.018)$ & $0.27(0.19-0.34)$ \\
\hline \multirow[t]{3}{*}{$\mathrm{Zn}$} & $243(36.6-645)$ & $1.29(0.34-2.9)$ & $35.7(16.7-70.1)$ & $55.6(41.5-69.7)$ & $0.17(0.094-0.25)$ & $20.6(15.2-28.3)$ \\
\hline & \multicolumn{3}{|l|}{ Test site 3 (willows) } & \multicolumn{3}{|c|}{ Reference site 3 (willows) } \\
\hline & 3 soil samples, $n=6$ & & 9 trees, $n=17$ & 1 soil sample, $n=2$ & & 2 trees, $n=4$ \\
\hline $\mathrm{Cd}$ & $0.16(0.13-0.19)$ & $0.068(0.015-0.18)$ & $0.22(0.07-0.46)$ & $0.31(0.29-0.33)$ & $0.115(0.104-0.125)$ & $0.86(0.75-1.04)$ \\
\hline $\mathrm{Cu}$ & $8.51(4.19-12.4)$ & $0.73(0.45-1.32)$ & $1.51(0.9-2.86)$ & $6.39(6.2-6.59)$ & $0.45(0.45-0.45)$ & $1.79(1.26-2.34)$ \\
\hline $\mathrm{Ni}$ & $3.46(2.09-4.69)$ & $0.27(0.039-0.79)$ & $0.36(0.12-0.69)$ & $9.18(8.89-9.47)$ & $0.43(0.36-0.49)$ & $0.51(0.33-0.72)$ \\
\hline $\mathrm{Zn}$ & $24.4(20-27.2)$ & $4.44(0.25-12)$ & $19.6(10.8-30)$ & $30.9(29.8-32)$ & $5.30(4.99-5.6)$ & $24.1(20-28.9)$ \\
\hline
\end{tabular}

significant differences were found, and at test site 3, only the concentration of $\mathrm{Cd}$ in willows differed significantly, which again was higher in the samples from reference site 3.

Difference between tree species At a significance level of $\alpha=5 \%$, willows show significantly higher concentrations of $\mathrm{Cd}, \mathrm{Cu}$, and $\mathrm{Zn}$ and poplar of $\mathrm{Ni}$ at test site 1 . The same result is obtained if concentrations in tree species from all sites together are tested for species differences. For reference site 1, poplar wood has significantly higher concentrations of $\mathrm{Zn}$ than willow wood (Table S5, Supporting Information).

Relation between concentration in wood and in soil Concentrations in wood versus concentrations in soil are shown in Figs. 2 (total concentration) and S2 (easily extractable concentration in soil). Measured concentrations in wood are highest for $\mathrm{Zn}>\mathrm{Cu}>\mathrm{Cd}>\mathrm{Ni}$ for both tree species. Except for $\mathrm{Cu}$ and $\mathrm{Zn}$ in poplar wood, concentrations in wood increase with increasing soil concentrations, and generally more in willow wood except for Ni. Table 2 shows the BCF values derived from the slopes of the linear regression between all concentrations in wood and soil, and the Y-intercept interpreted as background concentration in wood. Two of the eight linear regressions have an explained variance $\left(\mathrm{R}^{2}\right)$ above $70 \%$; four regression coefficients are significant at an error probability of $5 \%$. The highest slope of the regression line between concentrations in wood and in soil was obtained for $\mathrm{Cd}$, both for willows and poplars. Regressions were also made for the relation of concentration in wood to the easily extractable concentration in soil (Fig. S2, Supporting Information). Only in two (out of eight) cases, $\mathrm{R}^{2}$ improves ( $\mathrm{Cu}$ in willows, $\mathrm{Ni}$ in poplars, not shown). BCF values derived with Eq. (1) from average concentrations in wood and soils at each site are only useful for test site 1 . For all other sites, measured concentrations in wood are close to background. This can be seen by comparison of the Y-intercept of the BCF regressions (Table 2) with the mean concentrations in willow wood of the sites (Table 1), which are rather similar for all HM and the reference sites as well as test sites 2 and 3. Overall, willows take HM better up, and concentrations in wood show a stronger relation to those in soil. Consequently, willows are better indicators of subsurface HM than poplars.

\section{Discussion}

Level of soil contamination The usual background level in Danish soils is for $\mathrm{Cd}$ from 0.003 to $0.5 \mathrm{mg} \mathrm{kg}^{-1}$, for $\mathrm{Cu}$ at 

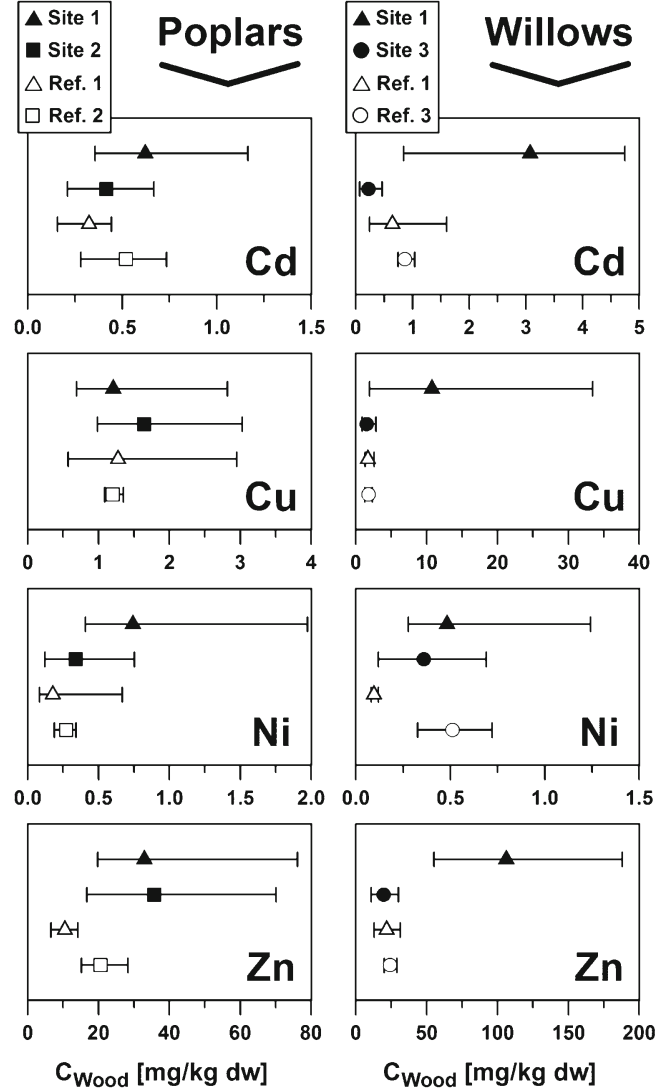

Fig. $1 \mathrm{HM}$ concentrations measured in the wood of poplars and willows from strongly polluted test site 1 , slightly polluted test site 2 , and nonpolluted test site 3 and reference sites (Ref. 1 to 3). Average concentrations, error bars indicate range

about $13 \mathrm{mg} \mathrm{kg}^{-1}$, for $\mathrm{Ni}$ from 0.1 to $50 \mathrm{mg} \mathrm{kg}^{-1}$, and for $\mathrm{Zn}$ between 10 and $300 \mathrm{mg} \mathrm{kg}^{-1}$ (average 40) (Miljøstyrelsen 1998). All measured total HM concentrations at test site 1 and the total concentrations of $\mathrm{Cd}$ and $\mathrm{Cu}$ in soils from test site 2 are above the background level. Concentrations in soils from test site 3 and from all reference sites are close to or even below the given background levels. In Denmark, two standards (Table S6, Supporting Information) are used to classify soil contamination levels as follows: (1) the soil quality standard, below which the soil can be used for any purpose, and (2) the enclosure standard, where exceeding concentrations indicate that the soil should be remediated or covered to avoid risks (Miljøstyrelsen 2010). Accordingly, test site 1 can be classified as strongly polluted and above enclosure standard for $\mathrm{Cd}, \mathrm{Ni}$, and $\mathrm{Zn}$; test site 2 can be classified as slightly polluted with only $\mathrm{Cd}$ above the quality standard. Test site 3 is not polluted; all investigated HM are below the quality standard.

Concentrations in tree cores The concentration data in Table 1 together with the Y-intercepts in Table 2 suggest that both willows and poplars show a certain background concentration in wood that is relatively stable at all reference sites and at the non-polluted test site 3 . This typical background concentration in wood is similar for poplars and willows and is about $0.5 \mathrm{mg} \mathrm{kg}^{-1}$ for $\mathrm{Cd}$ (between 0.5 and $0.9 \mathrm{mg} \mathrm{kg}^{-1}$ ), $1.6(1.1-1.8) \mathrm{mg} \mathrm{kg}^{-1} \mathrm{dw}$ for $\mathrm{Cu}, 0.3(0.1-0.5) \mathrm{mg} \mathrm{kg}^{-1}$ for $\mathrm{Ni}$, and 20 to $25 \mathrm{mg} \mathrm{kg}^{-1}$ for $\mathrm{Zn}$. Other studies show similar background concentrations in poplars and willows (Evangelou et al. 2013; Algreen et al. 2012). Algreen et al. measured concentrations in tree core samples from the former dump site Møringa in Norway. Concentrations of $\mathrm{Cd}$ in willows and poplars were similar and ranged from 0.33 to $0.76 \mathrm{mg} \mathrm{kg}^{-1}$ wood. This is comparable to the results found in this study, except for $\mathrm{Cd}$ in willows from the highly polluted test site 1 . The same was seen for $\mathrm{Cu}$, where the range in samples from Møringa (1.95 in reference willows and 1.33 to $1.66 \mathrm{mg} \mathrm{kg}^{-1}$ for poplars from reference and test) is close to the $\mathrm{Cu}$ contents in both willows and poplars from Danish reference and less polluted sites (average 1.11 to $1.79 \mathrm{mg} \mathrm{kg}^{-1}$, Table 1). The $\mathrm{Cu}$ concentration in willows from the Norwegian test site was $3.05 \mathrm{mg} \mathrm{kg}^{-1}$ and was clearly elevated, but less than in this study (10.7 mg kg${ }^{-1}$ in willows from test site 1$)$. Concentrations of $\mathrm{Zn}$ in poplars from Norway were 27 to $32.5 \mathrm{mg} \mathrm{kg}^{-1}$ (reference and test site), and in willows 15 and $32 \mathrm{mg} \mathrm{kg}^{-1}$ (first and second campaign, reference site) and 25 and $36 \mathrm{mg} \mathrm{kg}^{-1}$ (test site), which is also close to the results obtained in the present study, again with the exception of $\mathrm{Zn}$ in willows from the highly polluted test site 1 . Zacchini et al. (2011) studied the cadmium accumulation in roots and leaves from willows and poplars and found higher $\mathrm{Cd}$ content in poplar roots than in willow roots, 9,735 and $4,082 \mathrm{mg} \mathrm{kg}^{-1}$ respectively, and consequently lower $\mathrm{Cd}$ content in poplar leaves $\left(23 \mathrm{mg} \mathrm{kg}^{-1}\right)$ than in willow leaves $\left(376 \mathrm{mg} \mathrm{kg}^{-1}\right)$. The difference between $\mathrm{Cd}$ in exposed and control willows was higher than in our study. Reimann et al. (2001) and Djingova et al. (2004) studied the content of $\mathrm{Cd}, \mathrm{Cr}, \mathrm{Cu}, \mathrm{Ni}$, and other metals in leaves of willows and poplars. Their results confirm higher HM concentrations in willow (leaves) than in poplar (leaves), except for Cr. The capacity of Salix clones for biomass production and accumulation of heavy metals was tested by Mleczek et al. (2010). The maximum differences between the highest and lowest heavy metal content in shoots from the Salix clones were for $\mathrm{Cd} 84 \%, \mathrm{Cu} 90 \%$, mercury $167 \%, \mathrm{~Pb} 190 \%$, and $\mathrm{Zn} 36 \%$. In the study of Pietrini et al. (2010), a significant variability for translocation of $\mathrm{Cd}$ to woody parts was found among 10 poplar clones. The average content of $\mathrm{Cd}$ in the stems of poplar clones grown in the presence of $50 \mu \mathrm{M} \mathrm{CdSO}_{4}$ (at the end of the experiment) was $1.56 \mathrm{mg}$, ranging from 0.75 to $2.22 \mathrm{mg}$. The standard deviation was at $0.50 \mathrm{mg}$, and the coefficient of variation (CV) thus $32 \%$ (neither stem mass nor $\mathrm{Cd}$ concentration were given). These results show that uptake and concentration of HM in wood vary considerably with species and even with clone. High standard deviation and $\mathrm{CV}$ was also found in the previous study, but, nonetheless, a significant difference to the 
Fig. 2 Measured concentrations of $\mathrm{Cd}, \mathrm{Cu}, \mathrm{Ni}$, and $\mathrm{Zn}$ in wood (willow and poplar) versus measured total concentrations in soil. Lines represent linear fit (poplar dotted); black arrows indicate usual Danish background in soil (Miljøstyrelsen 1998)
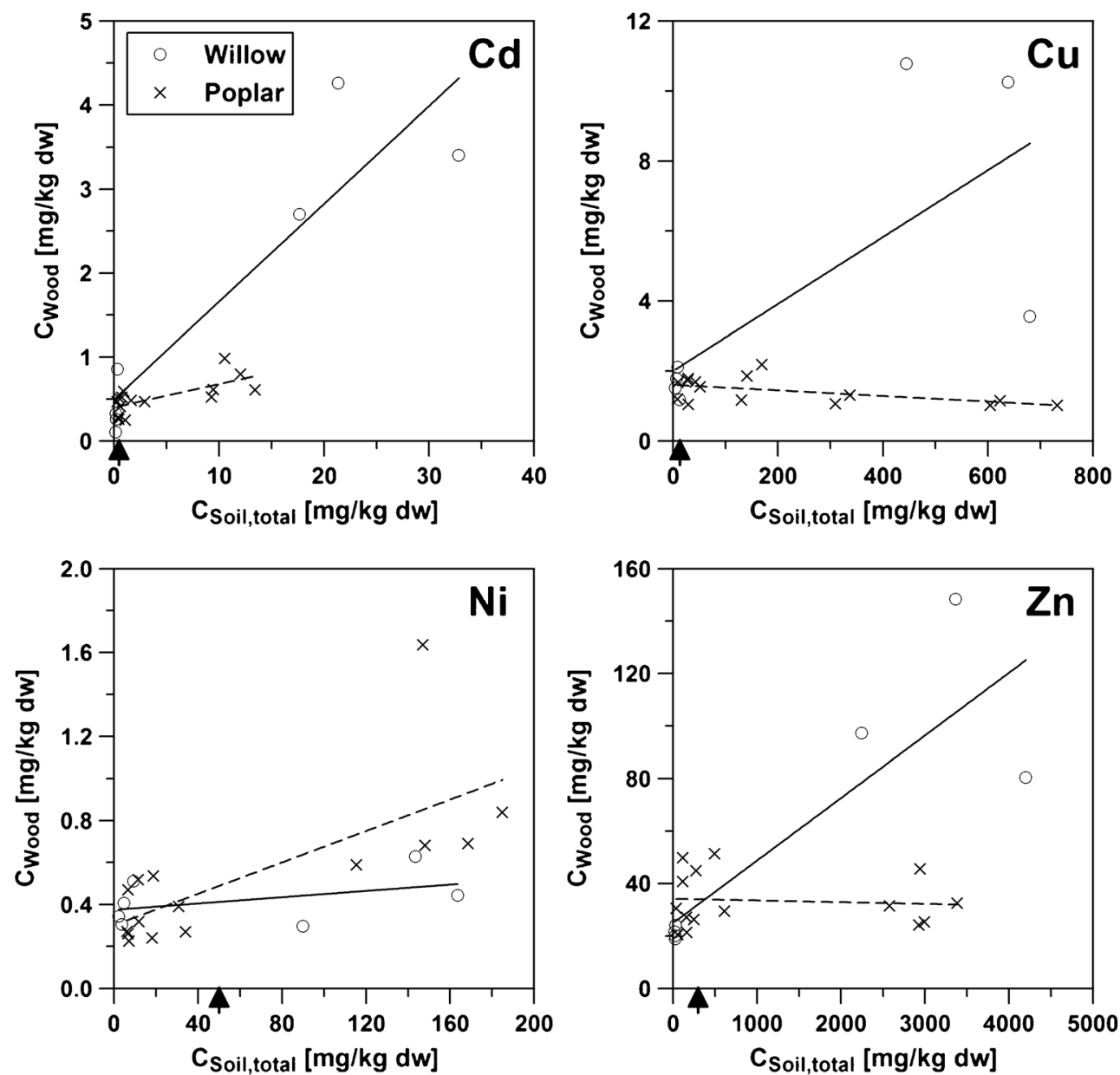

results from the reference site was obtained, despite the low number of sample events (Tables S3 and S4).

Willows (Salix sp.) and poplars (Populus sp.) both belong to the family of Salicaceae. In Norway (Algreen et al. 2012), most trees were from Salix caprea goat willows and $P$. nigra black poplars. At reference sites 1 and 3 and test site 3, Salix alba (white willow or silver willow) and at test and reference site $2 P$. nigra were sampled. At test site $1, S$. viminalis (basket willows) and balsam poplars ( $P$. trichocarpa) were most frequent. It seems that all these trees from the family Salicaceae have a rather constant background concentration of the studied HM in their wood, not varying much with habitat and species. If such a typical background level is confirmed in future studies, elevated concentrations can be detected without reference measurements. This simplifies phytoscreening for HM considerably.

Relation between concentration in wood and in soil The $\mathrm{BCF}$ values calculated for each site using Eq. (1), i.e., from the average concentrations, decrease for both species with increasing soil concentration (Table 2). Inspection of Fig. 2 offers some explanation; at low concentrations in soil, HM in wood are at almost constant level, independent of the HM in soil. Only at rather high concentrations in soil, levels in wood increase, too. This increase is not very well described by the linear fit, i.e., the transfer soil-to-plant is nonlinear with respect to soil concentrations. The regressions provide reasonable predictions only for the highest values. This is in accordance with recent findings by Tuovinen et al. (2011). It can be speculated that below a certain threshold, enzyme systems regulate HM uptake, and above, metals break through. Such pattern has been observed for essential heavy metals (McLaughlin et al. 2011), but also for salt (Trapp et al. 2008). The concentrations of $\mathrm{Cu}$ and $\mathrm{Zn}$ in poplar wood are rather unrelated to the respective concentrations in soil; the slope is even negative. Interestingly, both metals are known as essential for plant growth (Marschner 1995). The regression with the easily extractable concentration in soil improves the $\mathrm{R}^{2}$ only in two out of eight cases, indicating that the widely applied $\mathrm{CaCl}_{2}$-extractable fraction of $\mathrm{HM}$ in soil is not always a good predictor for the bioavailable fraction of HM. Smith el at. (2012) compared the residues of $\mathrm{Cu}$ and $\mathrm{Zn}$ and their effects in plants with the bioavailable concentration in soil determined by several extraction methods, among them $\mathrm{CaCl}_{2}$-extraction. The authors found that effects of $\mathrm{Cu}$ on plants best correlated with total concentration. 


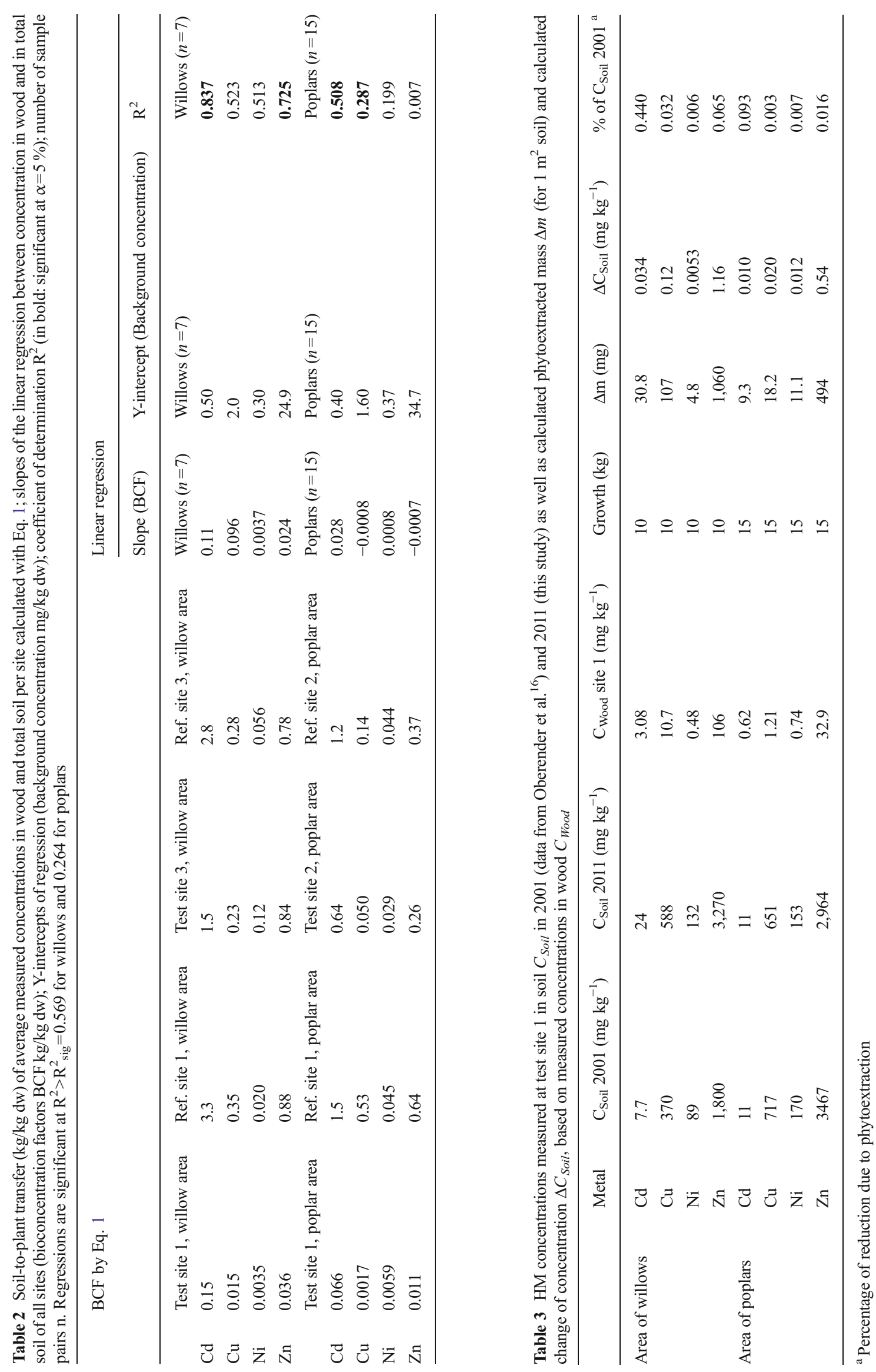


Mass balance calculations Test site 1 had been established as a test site for phytoremediation (cf. section test sites) in 1999. Table 3 compares the measured concentrations of HM in soil in 2001 (Oberender et al. 2009) and in 2011 (this study, from Table 1). The removal of HM from soil into wood by phytoextraction was calculated with Eqs. (2) and (3), based on measured concentrations in wood (also shown in Table 3). The extraction with willows is for $\mathrm{Cd}, \mathrm{Cu}, \mathrm{Ni}$, and $\mathrm{Zn}$ much higher (factors 5 to 8 ) than with poplars, despite the lower biomass production. The highest relative extraction (percent of 2001 soil concentration) is calculated for $\mathrm{Cd}$ and willows, but still less than $1 \%$ in 10 years. The extraction by poplars is below $1 \%$ for all four HM. The measured concentrations in 2011 are sometimes below, sometimes above, than those from 2001. There were small differences in the sampling method (depth in 2001, 0.85 to $1.25 \mathrm{~m}$; in 2011, $0.7 \mathrm{~m}$ ) and extraction procedure (aqua regia in $2001, \mathrm{HNO}_{3}$ in 2011). Due to the large variance of the HM analysis in soil, a real difference between the HM concentrations in soil determined in 2001 and 2011 cannot be seen.

The time it takes to reach legal standards in soil by phytoextraction alone was calculated with Eq (5). The slowest metal extraction is for $\mathrm{Ni}$, where the measured concentration $C(0)$ on the poplar area is $170 \mathrm{mg} \mathrm{kg}^{-1}$, the quality standard $C(t)$ is $30 \mathrm{mg} \mathrm{kg}^{-1}$, and BCF poplar is $0.0059 \mathrm{~kg} \mathrm{~kg}^{-1}$. With a $\Delta M_{\text {Wood }}$ of $1.5 \mathrm{~kg} \mathrm{~m}^{-2}$ year $^{-1}$ for poplar, and a $M_{\text {Soil }}$ of $910 \mathrm{~kg}$ as above, $k$ is $9.73 \times 10^{-6}$ year $^{-1}$, and $t$ is 178,360 years. Also with the more optimistic BCF from the reference site $\left(0.045 \mathrm{~kg} \mathrm{~kg}^{-1}\right)$, the extraction down to the standard still takes more than 20,000 years. Both numbers are not acceptable for an applied phytoremediation project. The calculated extraction efficiency is higher for the other sites, both because absolute concentrations in soil are lower, and relative bioconcentration factors (Table 2) are higher. However, none of the other sites is above the enclosure level that was set by the Danish EPA (Miljøstyrelsen 2010), and thus, no treatment is required. Trees on test site 1 have in 2013 partly been cut down, and the site is now used as parking place, perhaps also due to the slow extraction. Growing trees still is a reasonable way of using such highly polluted sites. Benefits of a plant cover are reduction of leaching and erosion (Hammer el at. 2003; Trapp and Karlson 2001). Moreover, forests provide a habitat for wildlife, relaxation for humans, fixing of $\mathrm{CO}_{2}$, and can be harvested.

Hammer et al. (2003) investigated the phytoextraction of Cd and $\mathrm{Zn}$ with willow (S. viminalis) in field trials in Switzerland. Initial total concentrations in soil were lower than in our study, namely $2.3 \mathrm{mg} \mathrm{kg}^{-1} \mathrm{Cd}$ and $650 \mathrm{mg} \mathrm{kg}^{-1} \mathrm{Zn}$. Concentrations of $\mathrm{Cd}$ and $\mathrm{Zn}$ in shoots (leaves and wood) decreased over the 5year period from 3.6 to $1.5 \mathrm{mg} \mathrm{kg}^{-1} \mathrm{Cd}$ and from 200 to $70 \mathrm{mg} \mathrm{kg}^{-1} \mathrm{Zn}$. Total extraction increased due to an increase of biomass production, and was at maximum about $60 \mathrm{~g} \mathrm{Cd}$ $\mathrm{ha}^{-1}\left(6 \mathrm{mg} \mathrm{m}^{-2}\right)$ per year and about $5 \mathrm{~kg} \mathrm{Zn} \mathrm{ha}^{-1}\left(500 \mathrm{mg} \mathrm{m}^{-2}\right)$ per year, which is two times more for $\mathrm{Cd}$ and five times more for $\mathrm{Zn}$ than in our study (Table 3).

\section{Conclusions}

Tree cores from willows and poplars from a strongly polluted, a moderately polluted, and a practically non-polluted test site and from reference sites were sampled and analyzed for heavy metals (HM). Concentrations of $\mathrm{Cd}, \mathrm{Cu}, \mathrm{Ni}$, and $\mathrm{Zn}$ in willow wood sampled from the highly polluted site were significantly elevated, compared to references, indicating the feasibility of phytoscreening for some HM with willows at strongly polluted sites. Differences were less clear for poplar. Background concentrations in wood from less and non-polluted sites were in a relatively narrow range and varied little with species, sampling time, and other conditions.

Extraction efficiencies of HM from the highest polluted site were best with willows due to the higher concentrations in wood and despite the lower biomass, but were still below $0.5 \%$ over 10 years for willows and $\mathrm{Cd}$, and below $1 \%$ for the other HM and for poplars. Nonetheless, we do recommend to plant trees on HM-contaminated sites due to several beneficial effects.

Acknowledgments This work was funded by the European Union (European Commission, FP7 contract no. 213161), project ModelPROBE (Model driven Soil Probing, Site Assessment and Evaluation), FP 7 contract no. 265364, and project TIMBRE (Tailored Improvement of Brownfield Regeneration in Europe). We thank Thomas Gudbrand and Michael Pedersen for supporting with sampling and sample preparation, Mikkel Algreen Jarmer for assistance during sampling, and Sinh Hy Nguyen for assistance with the chemical analysis. Thanks also to Lizzy Andersen, DHI, Julie Katrine Jensen, Kalvebod Miljøcenter, Sven Andresen, DanSteel A/S, John Flyvbjerg, Region Hovedstaden, and Svend Løw, Skov- og Naturstyrelsen for their assistance and data support concerning the test sites.

Open Access This article is distributed under the terms of the Creative Commons Attribution License which permits any use, distribution, and reproduction in any medium, provided the original author(s) and the source are credited.

\section{References}

Algreen M, Rein A, Legind CN, Amundsen CE, Gosewinkel KU, Trapp $\mathrm{S}$ (2012) Test of tree core sampling for screening of toxic elements in soils from a Norwegian site. Int J Phytoremediat 14(4):305-319

BAPPET (2008) BAse de données sur les teneurs en Eléments Traces métalliques de Plantes Potagères. http://www.sites-pollues. developpement-durable.gouv.fr/DocumentsDiagnostics.asp\#BAPPET (French). Accessed April 2012

BSELF (2012) Bayerisches Staatsministeriums für Ernährung Landwirtschaft und Forsten. http://www.tfz.bayern.de/ festbrennstoffe/17363 (German). Accessed April 2012

Burken JG, Vroblesky DA, Balouet JC (2011) Phytoforensics, dendrochemistry, and phytoscreening: new green tools for delineating contaminants from past and present. Environ Sci Technol 45(15): $6218-6226$ 
Djingova R, Kuleff I, Markert B (2004) Chemical fingerprinting of plants. Ecol Res 19(1):3-11

Evangelou MWH, Robinson BH, Günthardt-Goerg MS, Schulin R (2013) Metal uptake and allocation in trees grown on contaminated land: implications for biomass production. Int J Phytoremediat 15(1):77-90

Gopalakrishnan G, Negri MC, Minsker BS, Werth CJ (2007) Monitoring subsurface contamination using tree branches. Ground Water Monit Rem 27:65-74

Hammer D, Kayser A, Keller C (2003) Phytoextraction of Cd and Zn with Salix viminalis in field trials. Soil Use Manage 19(3):187-192

Holm O, Rotard W, Trapp S, Dési R (2011) Guide to Phytoscreening Using tree core sampling and chemical analyses to investigate contamination in the groundwater and soil. http://www.task.ufz.de/ data/Guide\%20to\%20Phytoscreening_20111121_FINAL17053. pdf. Accessed April 2012

Hohl R (1981) Die Entwicklungsgeschichte der Erde, 5th edn. Werner Dausien, Hanau, Germany

Larsen M, Burken J, Macháčková J, Karlson UG, Trapp S (2008) Using tree core samples to monitor natural attenuation and plume distribution after a PCE spill. Environ Sci Technol 42:1711-1717

Marschner H (1995) Mineral nutrition of higher plants. Academic, London

McLaughlin MJ, Smolders E, Degryse F, Rietra R (2011) Uptake of metals from soil into vegetation. In: Swartjes F (ed) Dealing with Contaminated Sites. From Theory towards Practical Application. Springer, Dordrecht, pp 325-367

Miljøstyrelsen (1998) Oprydning på forurenede lokaliteter Hovedbind, Vejledning fra Miljøstyrelsen Nr. 6. http://www.mst.dk/ Publikationer/Publikationer/1998/12/87-7909-783-9.htm. Accessed April 2012 (Danish)

Miljøstyrelsen (2010) Liste over kvalitetskriterier i relation til forurenet jord og kvalitetskriterier for drikkevand. http://www.mst.dk/NR/ rdonlyres/0AB0AF23-4BD6-4901-BCD9-43F6F6FD6FC1/ 124958/Kvalitetskriterierjord_og_drikkevandfinaljuniogjul.pdf. Accessed April 2012 (Danish)

Mleczek M, Rutkowski P, Rissmann I, Kaczmarek Z, Golinski P, Szentner K, Strazynska K, Stachowiak A (2010) Biomass productivity and phytoremediation potential of Salix alba and Salix viminalis. Biomass Bioenergy 34(9):1410-1418

Oberender A, Baun DL, Andersen L (2009) Fytoremediering af kulbrinteog anden forurening på nedlagt slamdepot, Miljøproject Nr. 1280, Miljøstyrelsen. http://www2.mst.dk/common/Udgivramme/Frame. asp?http://www2.mst.dk/udgiv/publikationer/2009/978-87-7052951-8/html/indhold.htm. Accessed April 2012 (Danish)

Pietrini F, Zacchini M, Iori V, Pietrosanti L, Bianconi D, Massacci A (2010) Screening of poplar clones for cadmium phytoremediation using photosynthesis, biomass, and cadmium content analyses. Int J Phytoremediat 12:105-120

Reimann C, Koller F, Frengstad B, Kashulina G, Niskavaara H, Englmaier $\mathrm{P}$ (2001) Comparison of the element composition in several plant species and their substrate from a 1,500,000 $\mathrm{km}^{2}$ area in Northern Europe. Sci Total Environ 278(1-3):87-112

Rock S (2003) Field evaluations of phytotechnologies. In: McCutcheon SC, Schnoor JL (eds) Phytoremediation: Transformation and Control of Contaminants. John Wiley \& Sons, Hoboken, New Jersey, USA, pp 905-924

Sachs L (1992) Angewandte Statistik, 7th edn. Springer, Berlin

Schumacher JG, Struckhoff GC, Burken JG (2004) Assessment of subsurface chlorinated solvent contamination using tree cores at the Front Street Site and a former dry cleaning facility at the Riverfront Superfund Site, New Haven, Missouri, 1999-2003, Scientific Investigations Report 2004-5049, U.S. Geological Survey. http://mo.water. usgs.gov/Reports/sir2004-5049-schu/toc.pdf. Accessed April 2012

Sheehan EM, Limmer MA, Mayer P, Karlson UG, Burken JG (2012) Time-weighted average SPME analysis for in planta determination of cVOCs. Environ Sci Technol 46:3319-3325

Skov og Naturstyrelsen (1989a) Forureningsundersøgelse af tidligere imprægneringsanstalt Stenholtvang, Hillerød Kommune, Fase 1. Skov og Naturstyrelsen, Copenhagen, Denmark (Danish)

Skov og Naturstyrelsen (1989b) Kemikalieaffaldsdepot 219-3, Stenholtvang Forureningsundersøgelse, Fase 2. Skov og Naturstyrelsen, Copenhagen, Denmark (Danish)

Sorek A, Atzmon N, Dahan O, Gerstl Z, Kushisin L, Laor Y, Mingelgrin U, Nasser A, Ronen D, Tsechansky L, Weisbrod N, Graber ER (2008) Phytoscreening: the use of trees for discovering subsurface contamination by VOCs. Environ Sci Technol 42(2):536-542

Smith BA, Greenberg B, Stephenson GL (2012) Bioavailability of copper and zinc in mining soils. Arch Environ Contam Toxicol 62:1-12

Trapp S, Karlson U (2001) Aspects of phytoremediation of organic compounds. J Soils Sediments 1(1):37-43

Trapp S, Larsen M, Legind CN, Burken J, Macháčková J, Karlson UG (2007) A guide to vegetation sampling for screening of subsurface pollution. http:/homepage.env.dtu.dk/stt/GuidetoVegetationSampling. pdf. Accessed April 2012

Trapp S, Feificova D, Rasmussen NF, Bauer-Gottwein P (2008) Plant uptake of $\mathrm{NaCl}$ in relation to enzyme kinetics and toxic effects. Env Exp Botany 64:1-7

Trapp S, Legind C (2011) Uptake of organic contaminants from soil into vegetation. In: Swartjes F (ed) Dealing with Contaminated Sites. From Theory towards Practical Application. Springer, Dordrecht, pp 369-408

Tuovinen TS, Roivainen P, Makkonen S, Kolehmainen M, Holopainen T, Juutilainen J (2011) Soil-to-plant transfer of elements is not linear: results for five elements relevant to radioactive waste in five boreal forest species. Sci Total Environ 410:191-197

Vroblesky DA (2008) User's guide to the collection and analysis of tree cores to assess the distribution of subsurface volatile organic compounds, U.S. Geological Survey Scientific Investigations Report 2008-5088, U.S. Geological Survey: Reston, Virginia, USA. http://pubs.usgs.gov/sir/2008/5088/pdf/sir2008-5088.pdf. Accessed April 2012

Vroblesky DA, Nietch CT, Morris JT (1999) Chlorinated ethenes from groundwater in tree trunks. Environ Sci Technol 33(3):510 515

Zacchini M, Iori V, Scarascia Mugnozza G, Pietrini F, Massacci A (2011) Cadmium accumulation and tolerance in Populus nigra and Salix alba. Biol Plant 55(2):383-386 